\title{
A sodium channel variant in Aedes aegypti as a candidate pathogen sensor for viral- associated molecular patterns
}

\author{
Cara Lee $^{\mathrm{a}}$, Alexis Jones ${ }^{\mathrm{a}}$, Danielle Kainz ${ }^{\mathrm{a}}$, Faatima Khan ${ }^{\mathrm{a}}$, and \\ Michael D. Carrithers ${ }^{\mathrm{a}, \mathrm{b}, \mathrm{c}}$
}

${ }^{a}$ Departments of Neurology, Pathology and Program in Cellular and Molecular Pathology, University of Wisconsin School of Medicine and Public Health and the

${ }^{b}$ William S. Middleton Memorial Veterans Hospital, Madison, WI, USA

${ }^{\mathrm{c}}$ Corresponding author

Email address: mcar1@uic.edu

Address for correspondence:

Michael Carrithers

Department of Neurology

University of Illinois College of Medicine

912 South Wood

Chicago, IL 60612 


\begin{abstract}
Recent work demonstrated that a splice variant of a human macrophage voltage-gated sodium channel expressed on endosomes acts as an intracellular sensor for dsRNA, a viral-associated molecular pattern. Here our goal was to identify a candidate gene in a clinically relevant invertebrate model with related cellular and pattern recognition properties. The para gene in drosophila and other insects encodes voltage-gated sodium channels with similar electrophysiological properties to those found in vertebrate excitable membranes. A database search revealed that the $A A E L 006019$ gene in Aedes aegypti, the yellow fever mosquito, encodes a voltage-gated sodium channel that is distinct from genes that encode para-like sodium channels. As compared to para-like channels, the protein products from this gene have deletions in the N-terminus and in the DII-DIII linker region. When over-expressed in an Aedes aegypti cell line, CCL-125, the AAEL006019 channel demonstrated cytoplasmic expression on vesicularlike organelles. Electrophysiologic analysis revealed that the channel mediates small inward currents that are enhanced by synthetic mimics of viral-derived ssRNA, R848 and ORN02, but not the dsRNA mimic, poly I:C. R848 treatment of CCL-125 cells that express high levels of the channels led to increased expression of RelA and Ago2, two mediators of insect innate immunity. These results suggest that the AAEL006019 channel acts as an intracellular pathogen sensor for ssRNA molecular patterns.
\end{abstract}

Key words: para, yellow fever mosquito, imidazolquinilone, RelA, ssRNA. 


\section{Introduction}

Voltage-gated sodium channels mediate evolutionarily conserved signaling mechanisms that are present in organisms as diverse as bacteria and mammals [1]. In excitable membranes, these channels regulate electrical signaling through the generation of action potentials. However, a range of non-canonical functions have been described.

Work from this laboratory has demonstrated that a novel human splice variant, macrophage $S C N 5 A$, regulates pathogen recognition and intracellular signaling. Unlike variants expressed in excitable tissues, the channel is expressed intracellularly on endosomes [2]. Because of an exon deletion that encodes a portion of the extracellular selectivity filter, human macrophage SCN5A does not generate action potentials and mediates small inward and outward cation currents [3]. Activation of human macrophage $S C N 5 A$ by cytoplasmic poly I:C, a mimic of viral dsRNA, increases the inward sodium current and leads to increased transcription of antiviral genes through an ATF2-dependent mechanism. Based on these results, we hypothesized that human macrophage $S C N 5 A$ is a pattern recognition molecule that initiates innate immune signaling.

We also postulated that this signaling pathway was evolutionarily conserved. Drosophila and other insects express products of the para sodium channel gene which regulate neuronal excitability [4]. We reasoned that variants of these sodium channel genes may utilize similar mechanisms as human macrophage SCN5A and be particularly relevant in insect vectors of viral disease. To test this hypothesis, we characterized a sodium channel variant encoded by the AAEL006019 gene in Aedes aegypti, the yellow fever mosquito [5]. Our data suggest that the AAEL006019 channel is an intracellular pathogen sensor that is activated by mimics of virallyderived ssRNA to regulate innate immune responses. 


\section{Materials and Methods}

\subsection{Cells.}

The Aedes aegypti cell line, CCL-125, was obtained from ATCC. Cells were grown in Leibovitz's L15 medium supplemented with 10\% fetal bovine serum (FBS), 10\% tryptose phosphate broth, glutamine, sodium pyruvate, and non-essential amino acids.

HEK-293F cells were obtained from Life Technologies and maintained as a suspension culture in 293 Freestyle media. Stably transfected cells were selected and maintained in hygromycin $(250 \mu \mathrm{g} / \mathrm{ml})$.

\subsection{Gene cloning and transfections.}

The XM_001657308.1 transcript (NCBI) encoded by the AAEL006019 gene was synthesized (Genscript) and cloned into the pCEP4-hygro vector (Life Technologies). Plasmid transfections of empty vector (pCEP4-hygro) or vector containing the AAEL006019 construct were performed using TransIT X2 transfection reagent (Mirus).

\subsection{Immunofluorescence.}

For immunofluorescence staining, cell monlayers were fixed in 4\% paraformaldehyde, washed with PBS, and blocked in PBS containing 5\% serum, 0.1\% Triton X-100, and 1\% BSA. Primary and secondary antibodies were diluted in blocking solution. Guinea pig anti-pan sodium channel antibody was obtained from Alomone and used at a dilution of 1:400. This antibody targets an epitope that is highly homologous in vertebrate, molluscan and insect sodium channels. Alexa 545-labelled phalloidin, and Alexa 488 goat anti-guinea pig were obtained from Life Technologies. For phagocytosis experiments, FluoSpheres sulfate microspheres ( $1 \mu \mathrm{m}$; 580/605; Life Technologies) were pre-treated with CCL-125 conditioned media for 60 min (1\% solids), washed, and added to CCL-125 cells in serum-free HBSS (0.01\% solids) for 60 min. 
Cells were then washed, fixed, and prepared for antibody staining. Fluorescent images were acquired and analyzed using a Zeiss Axiovert 200 fluorescent microscope equipped with an Axiocam-MRm CCD camera (Zeiss) and Axiovision version 4.8 software.

\subsection{Real time PCR.}

RNA purification, reverse transcription, $\mathrm{qPCR}$, and data analysis were performed as described previously [6]. Data was acquired on a Cepheid SmartCycler and analyzed by the $\Delta \mathrm{C}_{\mathrm{t}}$ method with normalization to either Ae. aegypti ribosomal gene Rp49 or human HMBS (hydroxymethylbilane synthase). TaqMan primers were obtained from Applied Biosystems/Life Technologies. Probe sequences for Rp49 and Ae. aegypti voltage-gated sodium channel transcripts were based on Martins et al. [7]. Primer sequences were: Rp49, F: 5'-ACATCGGTTACGGATCGAACAAG-3', R: 5'-TGTGGACCAGGAACTTCTTGAAG and probe 5'-FAMCACCCGCCATATGCT-NFQ; Ae a agypti sodium channel, F: 5'-ACCGACTTCATGCACTCATTCAT, R: 5' ACAAGCATACAATCCCACATGGA and probe 5'-FAM- ACCGACTTCATGCACTCATTCAT CCACTCGCCGCATAAT-NFQ; RelA F: 5'-GTCCGATCTGGTGATCTGTAAGTT-3', R: 5'-CGACCTTCTCACACAGCAAAATAAT, probe 5'-FAMCTGCCACCGGCTACC-NFQ; Ago2, F: 5'- CAACAATGCTCCAACCATCAAAGAA, R: 5'CCGTCAACCGTTTCGAAGTTATTT, probe: 5'-FAM-CCGACGCTCACTCCAA-NFQ.

\subsection{Whole cell patch clamp.}

Whole cell patch clamp analysis of transfected HEK-293F cells that were grown as suspension cultures was performed on a planar chip system (Nanion, Munich, Germany). Microchips had an equivalent resistance of 2-5 M . Cells were placed on the microchip, and giga- $\Omega$ seals (1-4 G $\Omega$ ) were obtained with an automated suction device (port-a-patch). Mean cell capacitance was $6.7 \pm 0.3 \mathrm{pF}(\mathrm{n}=9)$. Whole cell currents were recorded for $20 \mathrm{mS}$ in $20 \mathrm{mV}$ 
increments from -120 to $+80 \mathrm{mV}$ utilizing pClamp 10.3.1 software. Data were acquired at a sampling frequency of $20 \mathrm{kHz}$ and a low pass Bessel filter setting at $5 \mathrm{kHz}$. Capacitative transients and series resistance were compensated (approximately 80\%) with amplifier settings (Axopatch 200B) in conjuction with pClamp software. P/4 leak subtraction was performed for all recordings used for analysis. All recordings were performed at room temperature.

Intracellular solutions (pH 7.2, $285 \mathrm{mOsmol}$ ) contained either $50 \mathrm{mM} \mathrm{CsCl}, 10 \mathrm{mM}$ $\mathrm{NaCl}, 60 \mathrm{mM}$ Cs fluoride, $20 \mathrm{mM}$ EGTA and $10 \mathrm{mM}$ Hepes (Cs internal solution) or $50 \mathrm{mM}$ $\mathrm{KCl}, 10 \mathrm{mM} \mathrm{NaCl}, 60 \mathrm{mM} \mathrm{K}$ fluoride, $20 \mathrm{mM}$ EGTA and $10 \mathrm{mM}$ Hepes (K internal solution). For experiments with poly I:C or ORN-02 treatment, $1 \mu \mathrm{g} / \mathrm{ml}$ poly I:C or $500 \mathrm{ng} / \mathrm{ml}$ ORN-02 was added directly to the internal solution of the microchip.

Extracellular solutions (pH 7.4, $298 \mathrm{mOsmol}$ ) contained either $140 \mathrm{mM} \mathrm{NaCl}, 4 \mathrm{mM}$ $\mathrm{KCl}, 1 \mathrm{mM} \mathrm{MgCl} 2,2 \mathrm{mM} \mathrm{CaCl}_{2}, 5 \mathrm{mM}$ D-glucose and $10 \mathrm{mM}$ Hepes (Na external solution) or $100 \mathrm{mM}$ NMDG, $30 \mathrm{mM} \mathrm{CaCl} 2,10 \mathrm{mM}$ D-glucose and $20 \mathrm{mM}$ Hepes (NMDG-Ca external solution). As indicated, R848 (1 $\mu \mathrm{M}$; Invivogen) was added to the external bath solution.

Statistical analysis. Data were analyzed as indicated using ImageJ, Axiovision, Kaleidagraph (student t-test and ANOVA), and pClamp. 


\section{Results}

3.1. Identification of variants of voltage-gated sodium channel genes in the Ae. aegypti genome. Our initial goal was to identify sodium channel transcripts from Ae. aegypti that would be predicted to have a cytoplasmic localization and generate small peak currents as compared to the canonical para-like gene products. Based on database searches, we identified transcripts of the AAEL006019 gene as candidates [5]. As compared to the para genes, products of AAEL006019 contain deletions in a portion of the DII-DIII cytoplasmic linker and at the N-terminus (Fig. 1). These deletions are distinct from those in the human macrophage $S C N 5 \mathrm{~A}$ variant, which contains a deletion in the DIII S5-S6 extracellular selectivity filter [8]. However, a similar DII-DIII deletion has been described in a fetal variant of $S C N 5 A, \mathrm{NaV} 1.5 \mathrm{~d}$ [9]. That variant demonstrates a marked reduction in peak currents. Based on these data, our prediction was that AAEL006019 encodes products that have reduced peak currents, and, because of the N-terminal deletion, localize to intracellular organelles rather than the plasma membrane.

3.2. The AAEL006019 sodium channel variant localizes to cytoplasmic vesicles and phagosomes when expressed in CCL-125 cells.

The XM_001657308.1 transcript (NCBI) encoded by the AAEL006019 gene was cloned into an expression vector (pCEP4) and expressed in CCL-125 cells, an Ae. aegypti cell line. This line was originally derived from larvae and is permissive to infection with dengue virus [10]. Immunofluorescence staining for voltage-gated sodium channels revealed a high level of cytoplasmic, vesicular staining in cells transfected with plasmid containing the transcript (Fig. 2a). This staining pattern is similar to that observed for other intracellular voltage-gated sodium channels, including the human macrophage SCN5A channel. A low level of staining was 
observed in control-transfected (empty vector) CCL-125 cells that could reflect expression of baseline sodium channel expression in this cell line or nonspecific background staining.

We also examined whether or not the channels would be associated with phagosomes. The human macrophage SCN5A channel is expressed on late endosomes and is associated with phagosomes $[2,6]$. Following uptake of fluorescent micro-spheres in transfected CCL-125 cells, channel staining was observed on the surface of phagosomes (Fig. 2b). These results suggested that the AAEL006019 channel has a similar subcellular localization to the human macrophage SCN5A sodium channel.

\subsection{The AAEL006019 sodium channel variant mediates a small inward current in HEK-293F} cells.

Stably transfected HEK-293F cells lines were generated that express the AAEL006019 sodium channel and a hygromycin resistance gene or the resistance gene alone (control cells).

Electrophysiologic analysis revealed that a small inward current could be detected in the AAEL006019 cells that was not observed in control cells (Fig. 2b-d). This current was maximal at $-20 \mathrm{mV}$ and could be inhibited by a high dose of permethrin $(500 \mathrm{nM})$, a modulator of insect voltage-gated sodium channels (Fig. 2c-d). At the dose used, permethrin and related pyrethrins reduce peak sodium currents $[11,12]$. Replacement of extracellular sodium with NMDG markedly reduced the peak inward current (Fig. 2d).

Statistical analysis at $-20 \mathrm{mV}$ showed a current of $-23.24 \pm 0.92 \mathrm{pA} / \mathrm{pF}$ for untreated AAEL006019 cells $(\mathrm{n}=21 ; \underline{P}<0.001$ vs each condition, ANOVA), $-10.29 \pm 0.56 \mathrm{pA} / \mathrm{pF}$ with permethrin treatment $(n=14), 1.93 \pm 1.26$ for the NMDG condition $(n=9)$, and $-0.96 \pm 1.26$ $\mathrm{pA} / \mathrm{pF}$ for control cells $(\mathrm{n}=11)$. 
As with other channel variants that contain amino acid deletions such as human macrophage $S C N 5 A$ [3] and $\mathrm{NaV1.5 \textrm {d }}$ [9], this peak current was much smaller than that observed with full-length variants. However, unlike human macrophage SCN5A, the AAEL006019 channel did not modulate the outward, endogenous currents. This difference is likely due to a deletion in the extracellular selectivity filter in macrophage $S C N 5 A$; this deletion is not present in AAEL006019.

\subsection{R848 and ORN-02 increase the inward current mediated by the AAEL006019 sodium} channel variant.

We reasoned that $A A E L 006019$ may act as a viral pathogen sensor because of the activation of human macrophage SCN5A by intracellular dsRNA [3]. In addition, the role of Ae. aegypti as a vector of human viral pathogens suggested the presence of related anti-viral pathways in the two species. However, the presence of poly I:C $(1 \mu \mathrm{g} / \mathrm{ml})$ in the intracellular buffer did not result in activation of the AAEL006019 channel (Fig. 3b).

We next examined other potential viral-associated molecular patterns as channel activtors. Mimics of virally-derived ssRNA include RNA oligonucleotides that contain stretches of polyU and synthetic molecules such as the imidazolquinoline, R848 [13, 14]. In contrast to poly I:C, R848 (1 $\mu \mathrm{M})$ or ORN-02 $(500 \mathrm{ng} / \mathrm{ml}$; intracellular) increased the inward current in 293F-AAEL006019 cells (Figs. 3-4). This effect was inhibited by permethrin or replacement of extracellular sodium with NMDG and was not observed in control cells.

Statistical analysis of the peak current at $+20 \mathrm{mV}$ showed a current of $-65.79 \pm 3.73$ $\mathrm{pA} / \mathrm{pF}(\mathrm{n}=12)$ for $\mathrm{R} 848$ treatment of $293 \mathrm{~F}-$ AAEL006019 cells, $12.40+11.44 \mathrm{pA} / \mathrm{pF}(\mathrm{n}=18)$ for poly I:C treatment of 293F-AAEL006019 cells, $25.89 \pm 1.54 \mathrm{pA} / \mathrm{pF}(\mathrm{n}=14)$ for $\mathrm{R} 848+$ permethrin in the AAEL006019 condition, $-0.73 \pm 0.87 \mathrm{pA} / \mathrm{pF}(\mathrm{n}=16)$ for $\mathrm{R} 848$ in the presence of 
extracellular NMDG in the AAEL006019 condition, $-56.59 \pm 1.54 \mathrm{pA} / \mathrm{pF}$ ( $\mathrm{n}=12)$ for ORN-02 treatment (intracellular) in the AAEL006019 condition, and $1.10 \pm 4.25 \mathrm{pA} / \mathrm{pF}(\mathrm{n}=10)$ for $\mathrm{R} 848$ treatment in control cells (293F-hygromycin). ( $\underline{P}<0.001$ for R848 and ORN-02 treatment in 293F-AAEL006019 as compared to other conditions.) These results suggested that the AAEL006019 channel could act as a sensor for virally-derived ssRNA.

\subsection{R848 treatment increases expression of RelA and Ago2 transcripts in CCL-125 cells that} express AAEL006019 channel variant

Activation of the human macrophage $S C N 5 A$ channel by poly I:C increases expression of antiviral genes. To determine if a similar mechanism occurs in response to AAEL006019 activation, we treated CCL-125 cells with R848 and assessed expression of two genes that regulate insect innate immunity, Ae. aegypti RelA and Ago2. To examine transcriptional regulation, we transfected CCL-125 cells with a plasmid that contains an insert that encodes the AAEL006019 gene product or with control, empty vector plasmid. As assessed by real-time PCR, there was greater than a 100-fold increase in sodium channel transcripts in the AAEL006019-transfected cells (Fig. 4a). Statistical analysis revealed $283.0 \pm 51.3 \mathrm{mRNA}$ copies $/ R P 49 \times 10^{-3}$ in AAEL006019 transfected cell versus $2.3 \pm 0.3 \mathrm{mRNA}$ copies $/ R P 49 \times 10^{-3}$ in control transfected cells (n=4, $\underline{P}<0.05 ; R P 49$ is a ribosomal housekeeping gene).

Short-term treatment (4 hrs) with R848 (500 nM) led to an increase in expression of RelA and Ago 2 transcripts in CCL-125 cells transfected with the AAEL006019 transcript but not in control (empty vector) transfected cells (Fig. 4b-c). In AAEL006019-transfected cells, there were $8.9 \pm 0.7$ RelA $\mathrm{mRNA}$ copies $/ R P 49 \times 10^{-3}$ with $\mathrm{R} 848$ treatment versus $5.2 \pm 0.3$ RelA mRNA copies/RP49 $\times 10^{-3}(\mathrm{n}=4, \underline{P}<0.01)$ in vehicle treated cells; $42.30 \pm 4.90$ Ago 2 mRNA copies/RP49 $\mathrm{x} 10^{-3}$ with R848 treatment versus $29.60 \pm 4.4 \mathrm{Ago} 2 \mathrm{mRNA}$ copies $/ R P 49 \times 10^{-3}$ in vehicle treated 
cells $(\mathrm{n}=6, \underline{P}<0.01)$. In control transfected cells, there were $11.1 \pm 0.8$ RelA mRNA copies/RP49 $\mathrm{x} 10^{-3}$ with R848 treatment versus $10.3 \pm 2.3 \mathrm{mRNA}$ copies $/ R P 49 \times 10^{-3}$ in vehicle-treated cells;

$23.1 \pm 3.6$ Ago 2 mRNA copies $/ R P 49 \times 10^{-3}$ with $\mathrm{R} 848$ treatment versus $31.9 \pm 7.1$ Ago 2 mRNA copies $/ R P 49 \times 10^{-3}$ in vehicle-treated cells. These results suggested that activation of AAEL006019 increases transcription of immune-regulatory genes in response to a viralassociated molecular pattern. 


\section{Discussion}

We here propose that the AAEL006019 gene in Ae. aegypti encodes a voltage-gated sodium channel that acts as an intracellular sensor for virally-derived ssRNA. The voltage-gated sodium channel encoded by the AAEL006019 gene appears to be distinct from channels that are encoded by para-like genes. AAEL008297 and AAEL013277 can potentially encode for full-length para subtypes that have a longer N-terminal region and an intact DII-DIII linker and produce action potentials in neuronal cells [5]. The AAEL006019 channel shares some features with the human macrophage $S C N 5 A$ splice variant. The $A A E L 006019$ channel demonstrates an intracellular localization and contains a deletion that reduces peak currents; however, it is activated by mimics of ssRNA rather than intracellular dsRNA and does not contain a deletion in the extracellular selectivity filter.

These findings are relevant to the pathogenesis of viral disease in humans because $A e$. aegypti is a vector for several (+)ssRNA viruses. These include the flaviviruses that cause dengue and yellow fever and the alphavirus chikungunya [15]. Oral infection of mature $A e$. aegypti with dengue leads to a dose-dependent infection of the midgut with subsequent dissemination to the salivary glands [16]. Transmission of the virus to humans is dependent on a balance between Ae. aegypti innate immune mechanisms, permissive viral replication and host survival.

We hypothesize that the AAEL006019-regulated signaling is relevant to flavivirus infection and transmission through regulation of innate immunity regulated by the RelA and Dicer/Ago2 pathways. However, it remains unclear where the AAEL006019 sodium channel is expressed in larva and mature organisms. We selected the CCL-125 larval cell line for our studies because of its availability, potential infectivity, and epithelial-like morphology [10]. It is 
relevant to transovarial transmission of virus [16] and may mimic responses to virus by other epithelial-like cells that are present in the midgut and salivary glands.

Despite the limitations of the present study, we provide evidence of a potentially novel innate immune signaling pathway in an invertebrate model that partially mimics a related sodium channel-dependent mechanism in human macrophages. These mechanisms likely represent a complex interplay between evolutionarily conserved voltage-gated sodium channel genes and coevolution between host, vector and virus. 


\section{Acknowledgements}

This work was supported by a Merit Award (BLR\&D, 2 I01 BX000467-05) from the U.S. Department of Veterans Affairs.

\section{References}

[1] W. Catterall, A. Goldin, S. Waxman, International Union of Pharmacology. XLVII.

Nomenclature and structure-function relationships of voltage-gated sodium channels., Pharmacol Rev, 57 (2005) 397-409.

[2] M. Carrithers, S. Dib-Hajj, L. Carrithers, G. Tokmoulina, M. Pypaert, E. Jonas, S. Waxman, Expression of the voltage-gated sodium channel NaV1.5 in the macrophage late endosome regulates endosomal acidification., J Immunol, 178 (2007) 7822-7832.

[3] A. Jones, D. Kainz, F. Khan, C. Lee, M.D. Carrithers, Human macrophage SCN5A activates an innate immune signaling pathway for antiviral host defense, J Biol Chem, 289 (2014) 3532635340.

[4] K. Loughney, R. Kreber, B. Ganetzky, Molecular analysis of the para locus, a sodium channel gene in Drosophila, Cell, 58 (1989) 1143-1154.

[5] V. Nene, J.R. Wortman, D. Lawson, B. Haas, C. Kodira, Z.J. Tu, B. Loftus, Z. Xi, K. Megy, M. Grabherr, Q. Ren, E.M. Zdobnov, N.F. Lobo, K.S. Campbell, S.E. Brown, M.F. Bonaldo, J. Zhu, S.P. Sinkins, D.G. Hogenkamp, P. Amedeo, P. Arensburger, P.W. Atkinson, S. Bidwell, J. Biedler, E. Birney, R.V. Bruggner, J. Costas, M.R. Coy, J. Crabtree, M. Crawford, B. Debruyn, D. Decaprio, K. Eiglmeier, E. Eisenstadt, H. El-Dorry, W.M. Gelbart, S.L. Gomes, M. Hammond, L.I. Hannick, J.R. Hogan, M.H. Holmes, D. Jaffe, J.S. Johnston, R.C. Kennedy, H. Koo, S. Kravitz, E.V. Kriventseva, D. Kulp, K. Labutti, E. Lee, S. Li, D.D. Lovin, C. Mao, E. 
Mauceli, C.F. Menck, J.R. Miller, P. Montgomery, A. Mori, A.L. Nascimento, H.F. Naveira, C.

Nusbaum, S. O'Leary, J. Orvis, M. Pertea, H. Quesneville, K.R. Reidenbach, Y.H. Rogers, C.W. Roth, J.R. Schneider, M. Schatz, M. Shumway, M. Stanke, E.O. Stinson, J.M. Tubio, J.P. Vanzee, S. Verjovski-Almeida, D. Werner, O. White, S. Wyder, Q. Zeng, Q. Zhao, Y. Zhao, C.A. Hill, A.S. Raikhel, M.B. Soares, D.L. Knudson, N.H. Lee, J. Galagan, S.L. Salzberg, I.T. Paulsen, G. Dimopoulos, F.H. Collins, B. Birren, C.M. Fraser-Liggett, D.W. Severson, Genome sequence of Aedes aegypti, a major arbovirus vector, Science, 316 (2007) 1718-1723.

[6] L.M. Carrithers, P. Hulseberg, M. Sandor, M.D. Carrithers, The human macrophage sodium channel NaV1.5 regulates mycobacteria processing through organelle polarization and localized calcium oscillations, FEMS Immunol Med Microbiol, 63 (2011) 319-327.

[7] A.J. Martins, L.P. Brito, J.G. Linss, G.B. Rivas, R. Machado, R.V. Bruno, J.B. Lima, D. Valle, A.A. Peixoto, Evidence for gene duplication in the voltage-gated sodium channel gene of Aedes aegypti, Evolution, medicine, and public health, 2013 (2013) 148-160.

[8] K. Rahgozar, E. Wright, L.M. Carrithers, M.D. Carrithers, Mediation of Protection and Recovery From Experimental Autoimmune Encephalomyelitis by Macrophages Expressing the Human Voltage-Gated Sodium Channel NaV1.5, J Neuropathol Exp Neurol, 72 (2013) 489-504. [9] J.A. Camacho, S. Hensellek, J.S. Rougier, S. Blechschmidt, H. Abriel, K. Benndorf, T. Zimmer, Modulation of Nav1.5 channel function by an alternatively spliced sequence in the DII/DIII linker region, J Biol Chem, 281 (2006) 9498-9506.

[10] N. Wikan, A. Kuadkitkan, D.R. Smith, The Aedes aegypti cell line CCL-125 is dengue virus permissive, Journal of virological methods, 157 (2009) 227-230.

[11] O. Lowenstein, A method of physiological assay of pyrethrum extracts, Nature, 150 (1942) $760-762$. 
[12] P.G. Burt, RE, The site of action of pyrethrin I in the nervous system of the cockroach periplaneta americana, Ent. exp. \& appl., 14 (1971) 179-189.

[13] H. Tanji, U. Ohto, T. Shibata, K. Miyake, T. Shimizu, Structural reorganization of the Tolllike receptor 8 dimer induced by agonistic ligands, Science, 339 (2013) 1426-1429.

[14] H. Tanji, U. Ohto, T. Shibata, M. Taoka, Y. Yamauchi, T. Isobe, K. Miyake, T. Shimizu, Toll-like receptor 8 senses degradation products of single-stranded RNA, Nature structural \& molecular biology, 22 (2015) 109-115.

[15] E.A. Gould, T. Solomon, Pathogenic flaviviruses, Lancet, 371 (2008) 500-509.

[16] M.I. Salazar, J.H. Richardson, I. Sanchez-Vargas, K.E. Olson, B.J. Beaty, Dengue virus type 2: replication and tropisms in orally infected Aedes aegypti mosquitoes, BMC Microbiol, 7 (2007) 9. 


\section{Figure legends}

Fig. 1. The $A A E L 006019$ sodium channel localizes to cytoplasmic vesicles and phagosomes when expressed in CCL-125 cells. a. The AAEL006019 sodium channel variant was expressed in the Aedes aegypti cell line CCL-125. Immunofluorescence staining was performed with an anti-pan sodium channel antibody that recognizes a conserved epitope in mammalian, molluscan and invertebrate channel and revealed a vesicular-type, cytoplasmic staining pattern (green) in transfected cells (bottom micrographs) that express a high level of the gene product but much less intense staining in control transected cells (top). Phalloidin staining to label F-actin is shown in red, and DAPI nuclear staining in blue. b. CCL-125 cells that express the AAEL006019 sodium were challenged with coated fluorescent microspheres (red). Sodium channel staining (green) demonstrated the presence of staining associated with phagosomes. Scale bars, $10 \mu \mathrm{m}$ )

Fig. 2. The $A A E L 006019$ sodium channel mediates a small inward current. a. $A A E L 006019$ was stably transfected into HEK-293F. Anti-pan sodium channel staining is shown in green and demonstrates surface expression in the AAEL006019 cells (top). Background staining in cells stably transfected with the hygromycin resistance gene alone (293F-pCEP4) did not demonstrate cell surface staining and a minimal degree of background cytoplasmic staining (scale bar, $5 \mu \mathrm{m}$ ). b. Patch clamp analysis revealed an endogenous outward current in 293F-pCEP4 control cells (top tracing) and the presence of a small inward current (arrow, second tracing from top) in addition to the endogenous outward current in 293F-AAEL006019 cells. R848, a synthetic viralassociated molecular pattern, stimulated an increase in the inward current (bottom tracing, analysis shown in Fig. 3). c-d. I-V curve analysis of tracings performed in the absence of viralassociated molecular patterns showed a maximal inward current in the 293F-AAEL006019 cells that was maximal at $-20 \mathrm{mV}$. This inward current was not observed in 293F-pCEP4 control 
cells, was reduced by treatment with high dose permethrin $(500 \mathrm{nM})$, a modulator of insect voltage-gated sodium channels, and was not present when extracellular sodium was replaced with NMDG. Statistical analysis at $-20 \mathrm{mV}$ showed a current of $-23.24 \pm 0.92 \mathrm{pA} / \mathrm{pF}$ for untreated AAEL006019 cells ( $\mathrm{n}=21 ; \underline{P}<0.001$ vs each condition, ANOVA), $-10.29 \pm 0.56 \mathrm{pA} / \mathrm{pF}$ with permethrin treatment $(n=14), 1.93 \pm 1.26$ for the NMDG condition $(n=9)$, and $-0.96 \pm 1.26$ $\mathrm{pA} / \mathrm{pF}$ for control cells $(\mathrm{n}=11)$. Pooled recordings were from 22 cells for the AAEL006019 conditions and 4 cells from controls.

Fig. 3. R848 and ORN-02 increase the inward current mediated by AAEL006019. a-b. Treatment of 293F-AAEL006019 cells with the viral-associated molecular patterns $\mathrm{R} 848(1 \mu \mathrm{M})$ or ORN-02 $(500 \mathrm{ng} / \mathrm{ml}$; intracellular) increased the inward current and demonstrated a maximal effect at $+20 \mathrm{mV}$. This effect was not observed with either poly I:C ( $1 \mu \mathrm{g} / \mathrm{ml}$; intracellular) treatment of 293F-AAEL006019 cells or with R848 treatment of 293F-pCEP4 control cells. The R848 effect in 293F-AAEL006019 cells was blocked by either high dose permethrin (500 nM) or replacement of extracellular sodium with NMDG. Statistical analysis at $+20 \mathrm{mV}$ showed a current of $-65.79 \pm 3.73 \mathrm{pA} / \mathrm{pF}(\mathrm{n}=12)$ for $\mathrm{R} 848$ treatment of $293 \mathrm{~F}-A A E L 006019$ cells, $12.40 \pm$ $11.44 \mathrm{pA} / \mathrm{pF}(\mathrm{n}=18)$ for poly I:C treatment of $293 \mathrm{~F}-A A E L 006019$ cells, $25.89 \pm 1.54 \mathrm{pA} / \mathrm{pF}$ ( $\mathrm{n}=14)$ for $\mathrm{R} 848+$ permethrin in the AAEL006019 condition, $-0.73 \pm 0.87 \mathrm{pA} / \mathrm{pF}$ ( $\mathrm{n}=16)$ for $\mathrm{R} 848$ in the presence of extracellular NMDG in the AAEL006019 condition, $-56.59 \pm 1.54 \mathrm{pA} / \mathrm{pF}$ $(\mathrm{n}=12)$ for ORN-02 treatment (intracellular) in the AAEL006019 condition, and $1.10 \pm 4.25$ $\mathrm{pA} / \mathrm{pF}(\mathrm{n}=10)$ for $\mathrm{R} 848$ treatment in control cells (293F-pCEP4). ( $\underline{P}<0.001$ for R848 and ORN02 treatment in 293F-AAEL006019 as compared to other conditions.)

Fig. 4. R848 treatment increases transcription of immune-related genes in CCL-125 that express high levels of the AAEL006019 sodium channel. A. CCL-125 cells, an Aedes aegypti 
cell line, were transfected with a plasmid that encodes the AAEL006019 sodium channel variant. QPCR analysis revealed a greater than 100-fold increase in sodium channel transcripts as compared to control transfected cells $\left(283.0 \pm 51.3 \mathrm{mRNA}\right.$ copies $/ R P 49 \times 10^{-3}$ in AAEL006019 transfected cell versus $2.3 \pm 0.3 \mathrm{mRNA}$ copies $/ R P 49 \times 10^{-3}$ in control transfected cells, $\mathrm{n}=4$, $\underline{P}<0.05 ; R P 49$ is a ribosomal housekeeping gene). B-C. Treatment with $\mathrm{R} 848$ ( $1 \mu \mathrm{M}$ for $4 \mathrm{hrs})$ led to an increase in RelA and Ago2 transcripts in CCL-125 in cells that expressed high levels of AAEL006019 transcripts but not in control transfected cells. In AAEL006019-transfected cells, there were $8.9 \pm 0.7$ RelA $\mathrm{mRNA}$ copies/RP49 $\times 10^{-3}$ with R848 treatment versus $5.2 \pm 0.3$ RelA mRNA copies $/ R P 49 \times 10^{-3}$ in vehicle-treated cells $(\mathrm{n}=4, \underline{P}<0.01) ; 42.30 \pm 4.90$ Ago 2 mRNA copies $/ R P 49 \times 10^{-3}$ with R848 treatment versus $29.60 \pm 4.4$ Ago $2 \mathrm{mRNA}$ copies $/ R P 49 \times 10^{-3}$ in vehicle-treated cells $(\mathrm{n}=6, \underline{P}<0.01)$. In control transfected cells, there were $11.1 \pm 0.8$ RelA mRNA copies $/ R P 49 \times 10^{-3}$ with R848 treatment versus versus $10.3 \pm 2.3$ RelA mRNA copies $/ R P 49 \times 10^{-3}$ in vehicle-treated cells; $23.1 \pm 3.6$ Ago 2 mRNA copies $/ R P 49 \times 10^{-3}$ with R848 treatment versus $31.9 \pm 7.1 \mathrm{Ago} 2 \mathrm{mRNA}$ copies $/ R P 49 \times 10^{-3}$ in vehicle-treated cells.

\section{Supplemental figure.}

Fig. S1. Alignment of the AAEL006019 protein product with the Ae. aegypti para voltagegated sodium channel demonstrates deletions at the N-terminus and in a portion of the DIIDIII cytoplasmic linker. 
F-actin

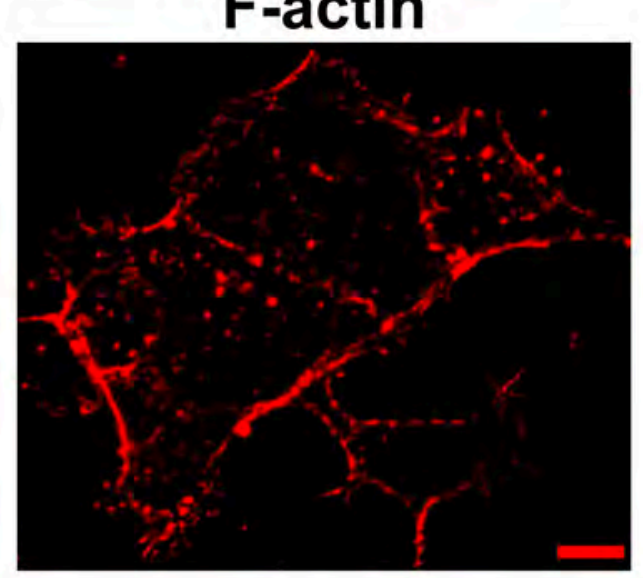

Merge + DAPI

\section{CCL-125 (AAEL006019)}

\section{Sodium Channel}

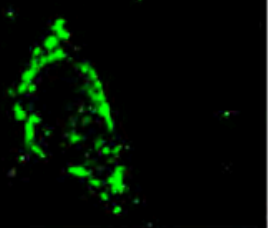

B

Sodium Channel

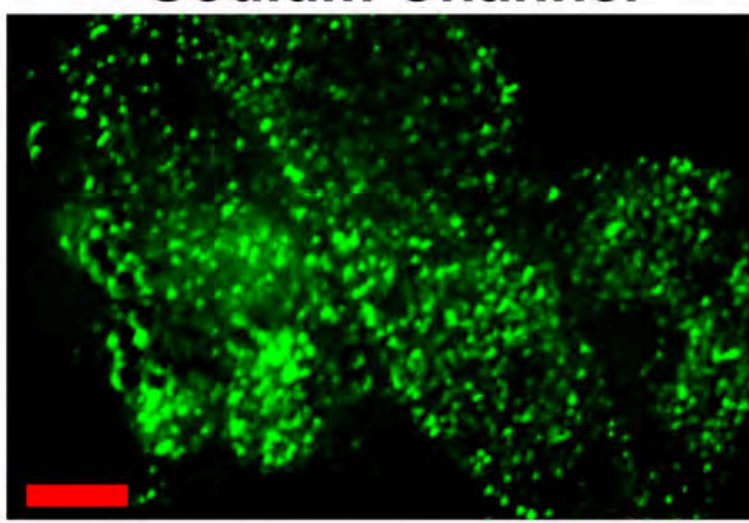

Detail

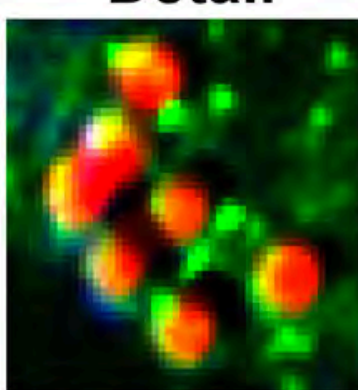

F-actin

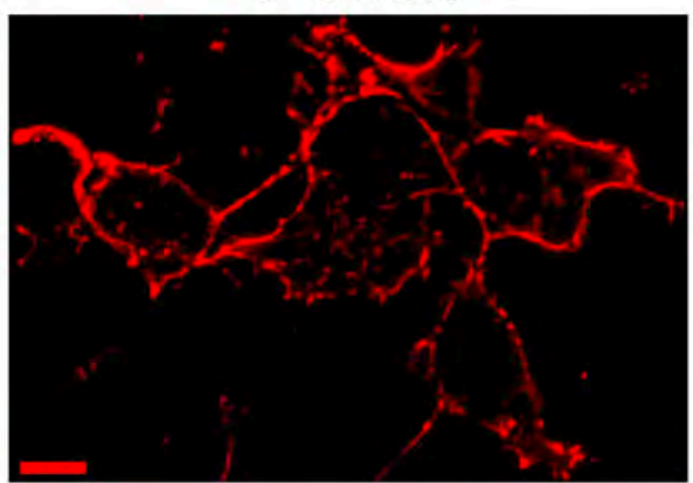

Merge + DAPI

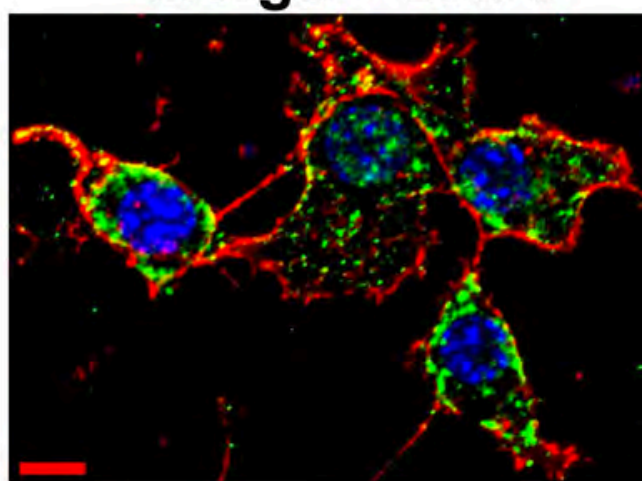

Fluo-spheres

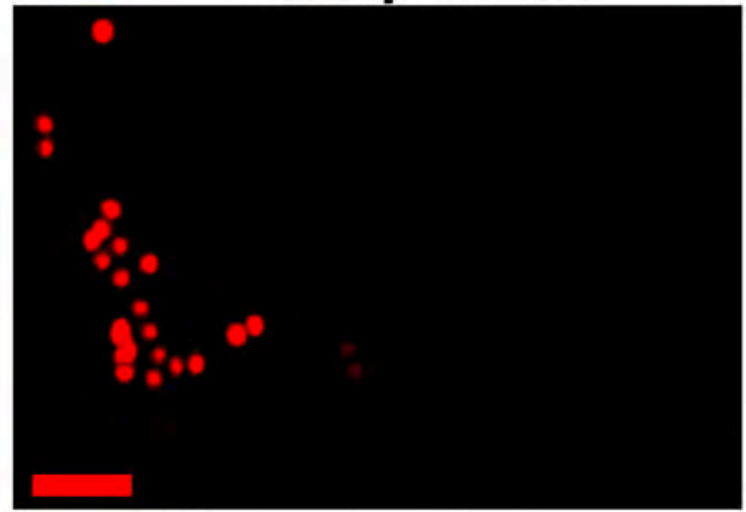

Merge + DAPI

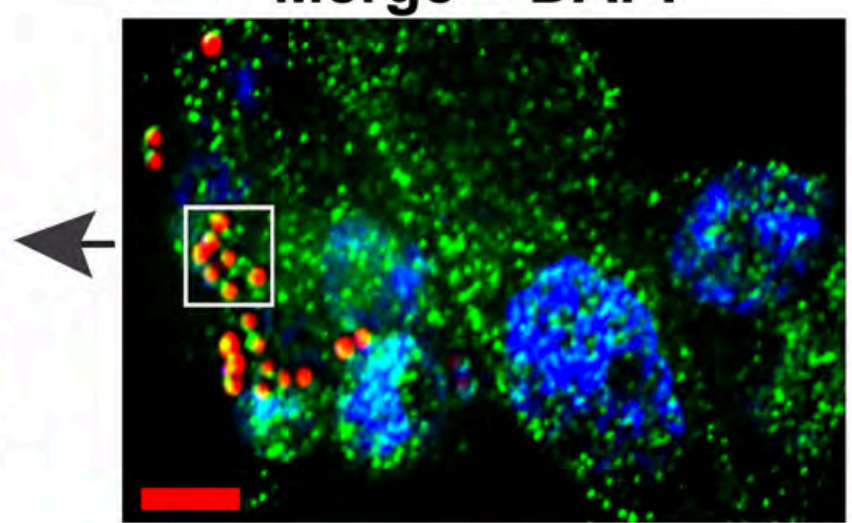

Figure 1 


\section{F (AAEL006019)}

Sodium Channel + DAPI

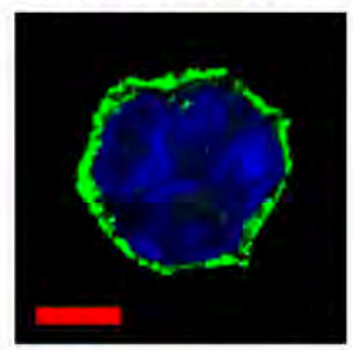

293F (empty vector) Sodium Channel + DAPI
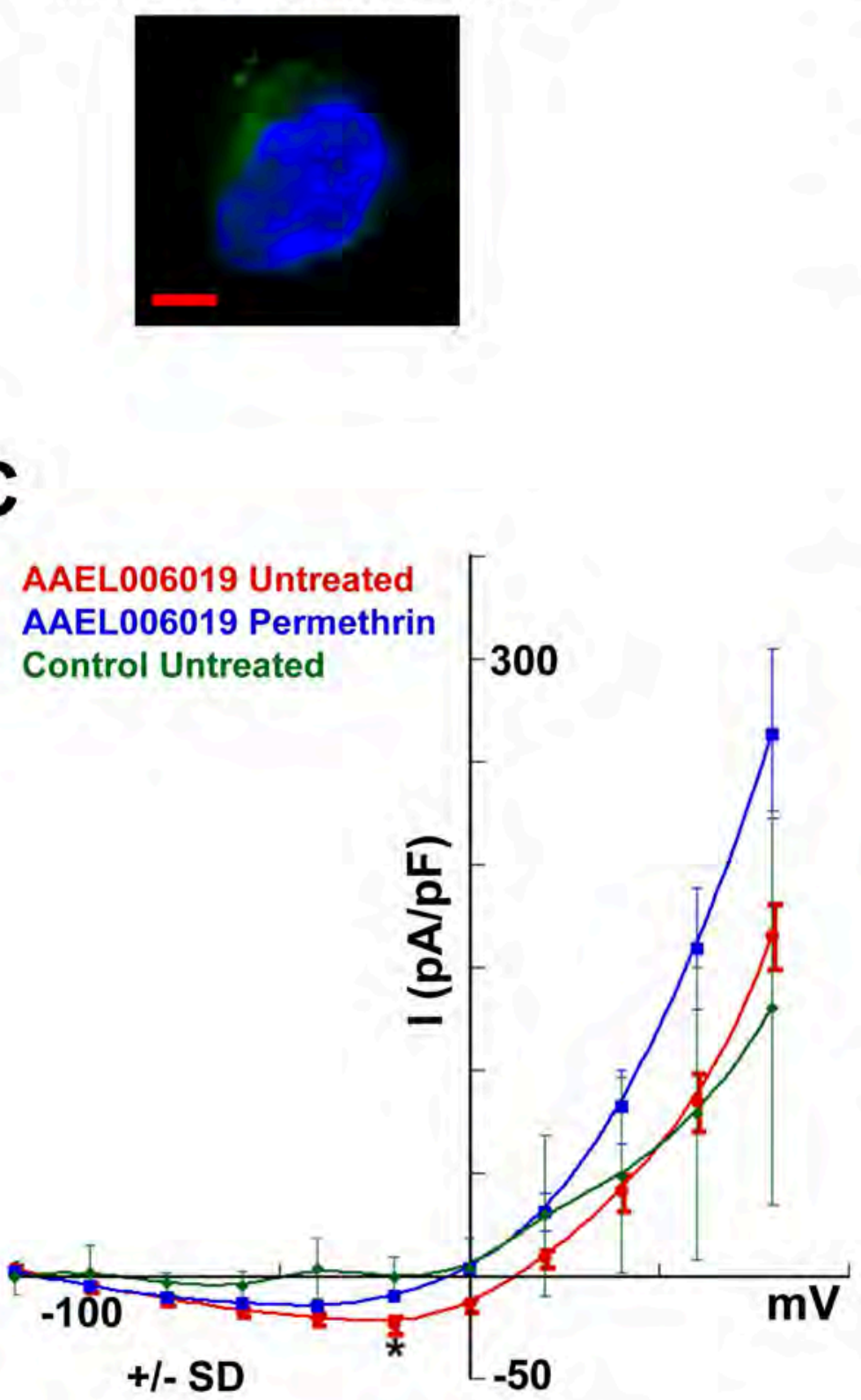

293F-pCEP4 Untreated Cs(int) $\mathrm{Na}$ (ext)

\section{F-AAEL006019 Untreated} $\mathrm{Cs}$ (int) $\mathrm{Na}$ (ext)

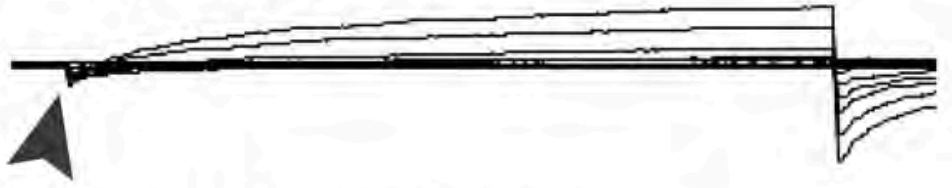

\section{F-AAEL006019 R848 Cs(int) $\mathrm{Na}$ (ext)}

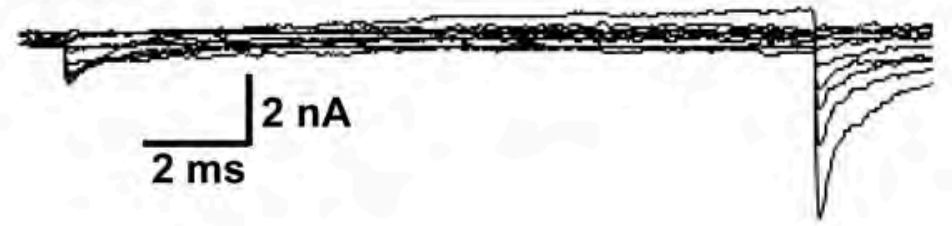

D

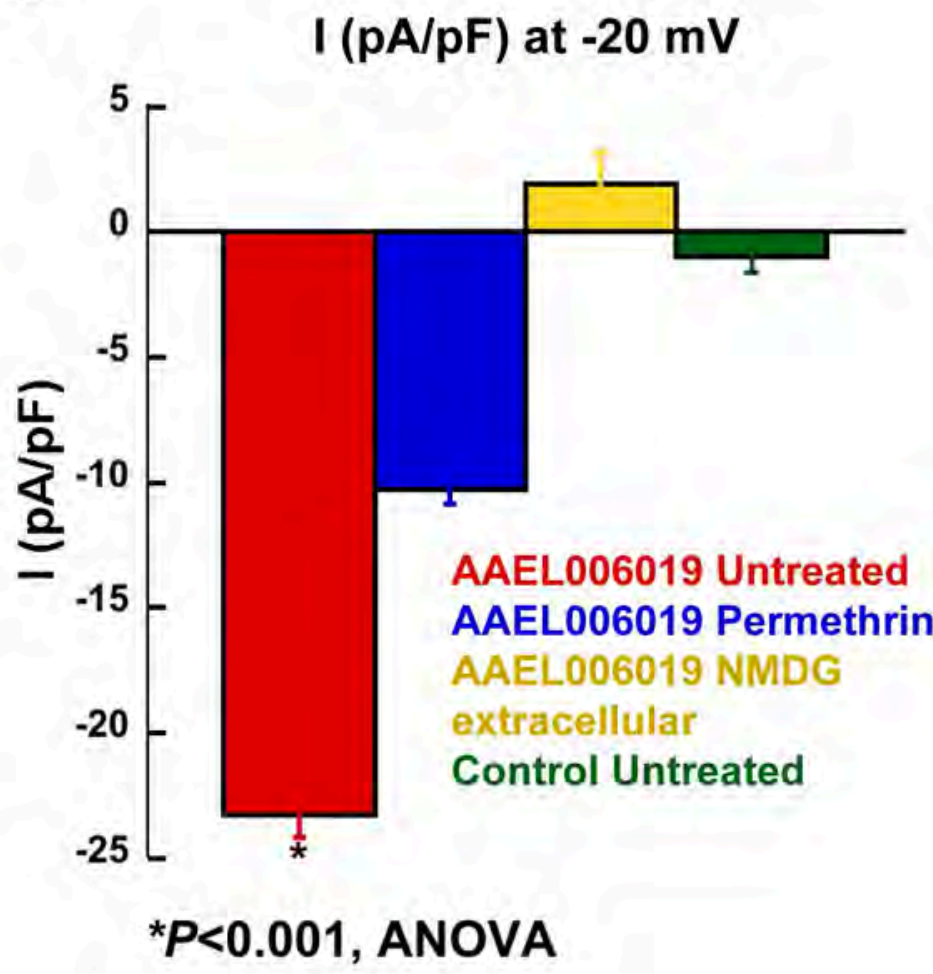


AAEL006019 R848

AAEL006019 R848/

Permethrin

Control R848

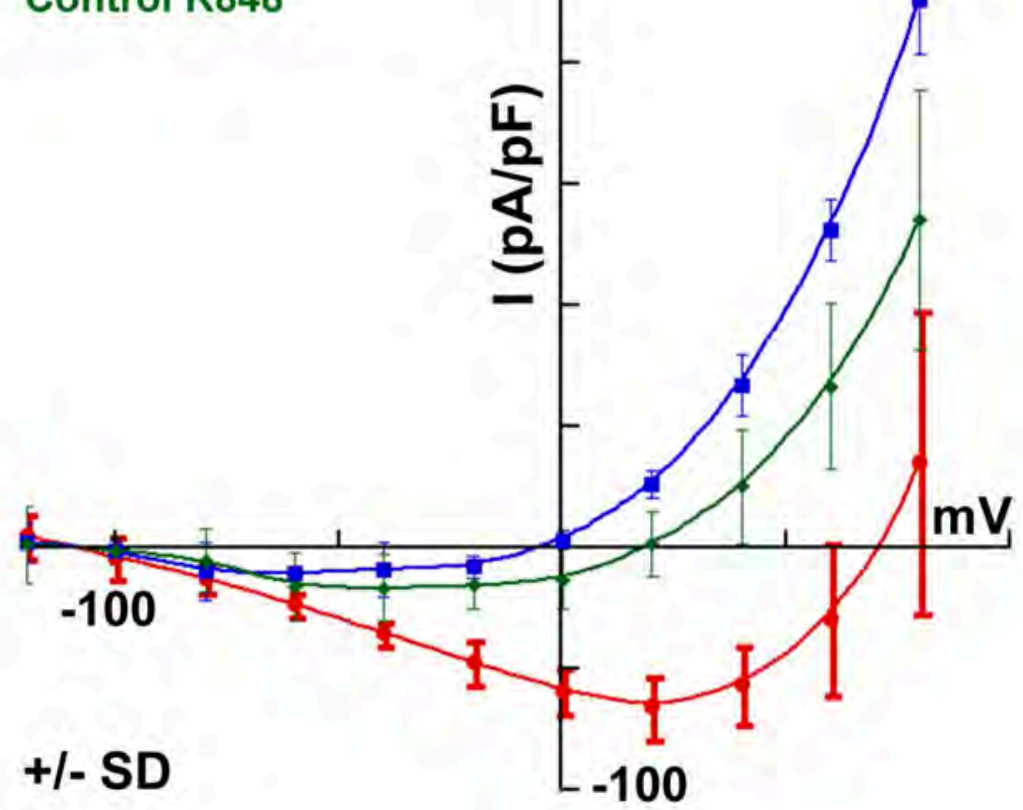

B

AAEL006019 R848

AAEL006019 R848/Permethrin

AAEL006019 R848/NMDG extracellular

AAEL006019 Poly I:C

AAEL006019 ORN-02

Control R848

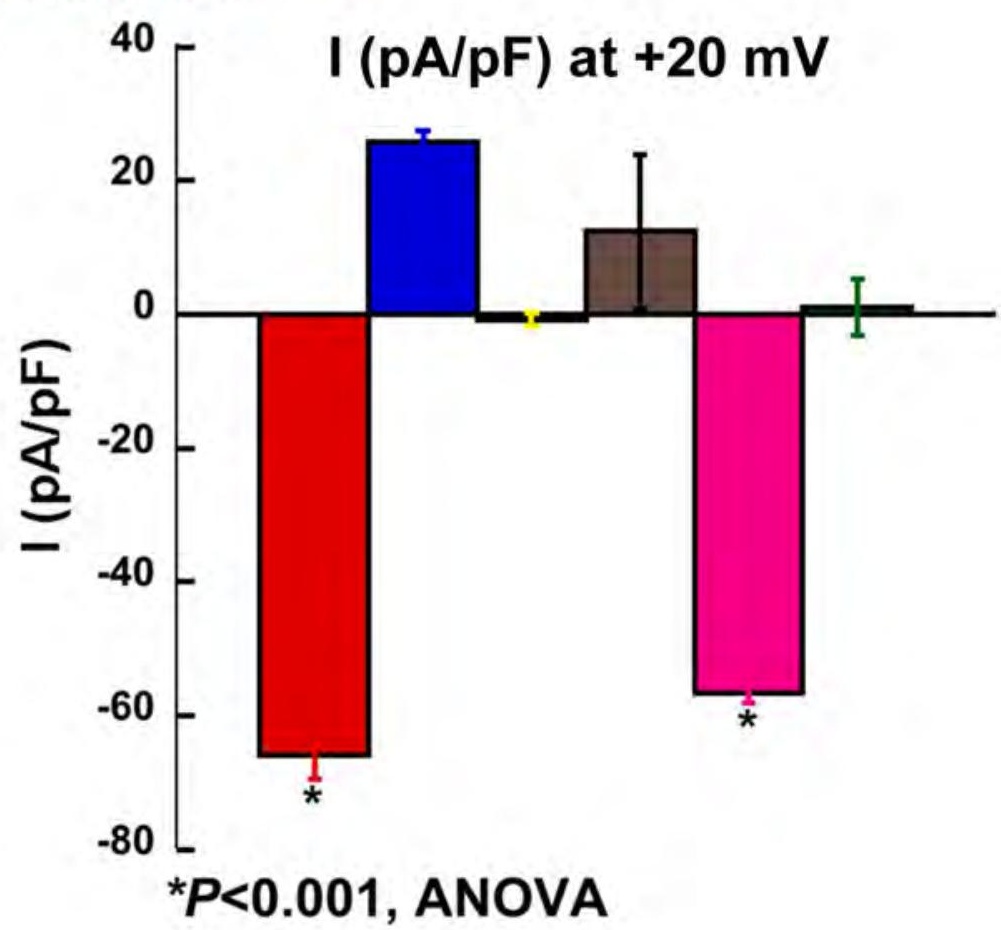

Figure 3 


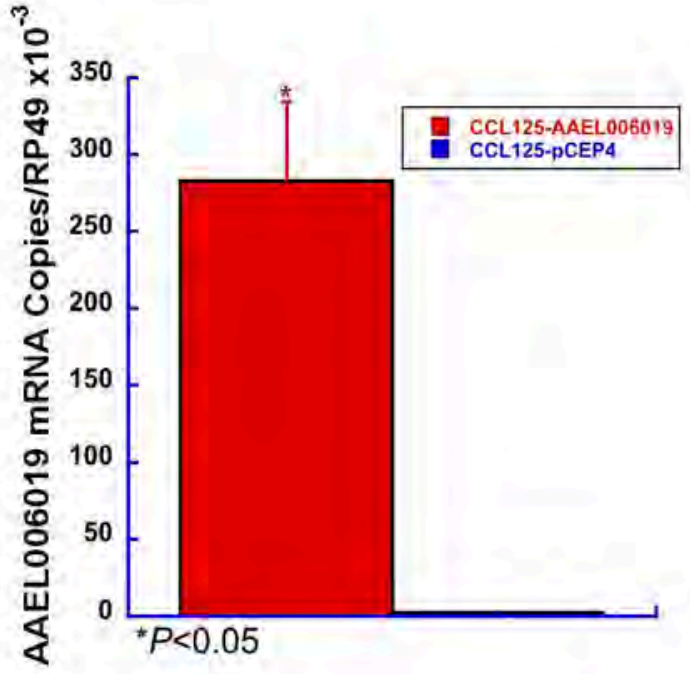

B

CCL125-AAEL006019
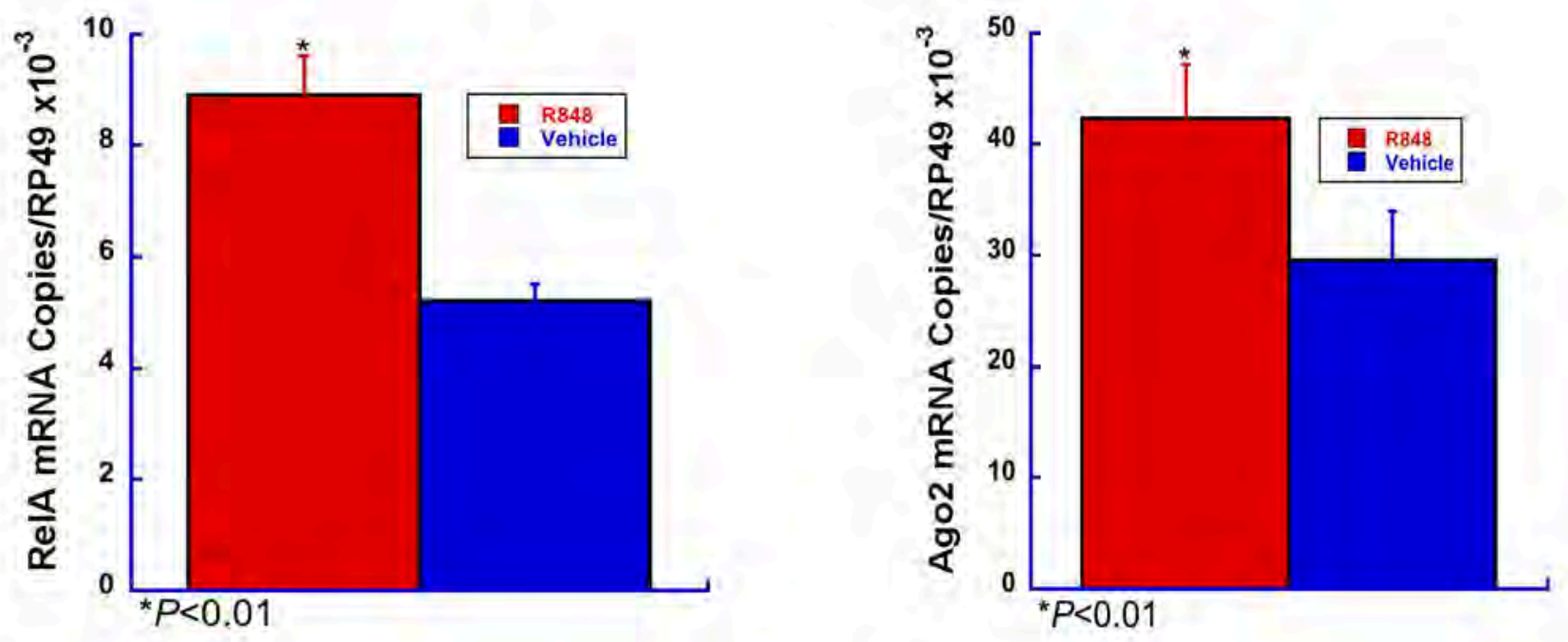

C

CCL125-pCEP4
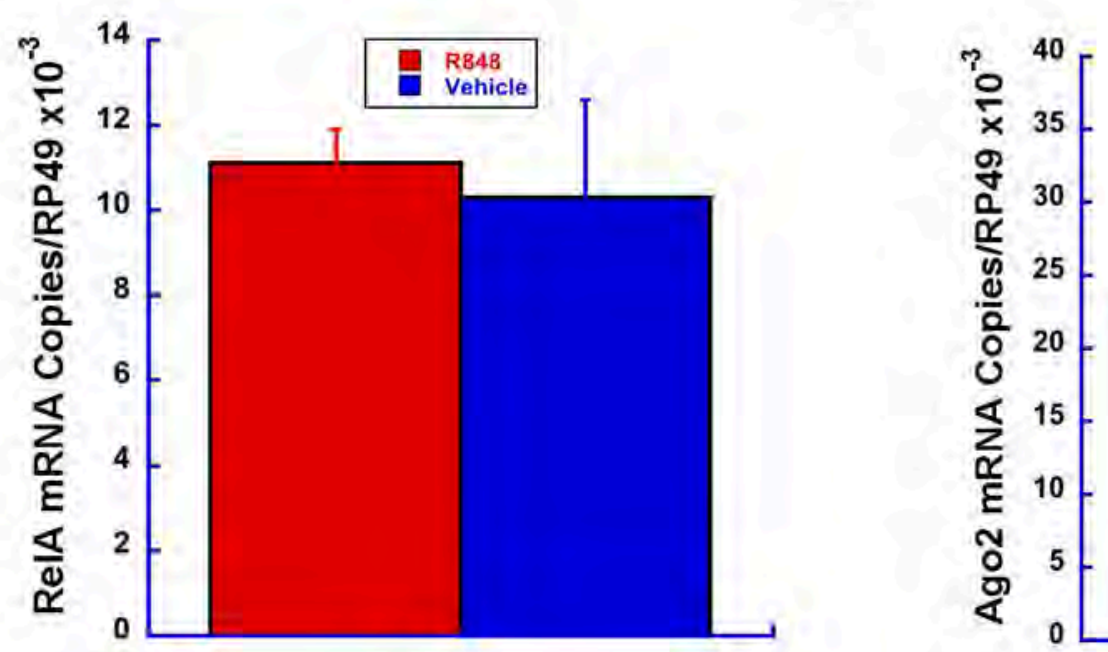

Figure 4 
EVIFTGIYTFESAVKVMARGE TLDPFTYLRDAWNWLDEVVIALAYVTYGIDLGNLAALRT 240 MGIDLGHLAALIRT

FRVI.RALKTVAIVPGL.KTTVGAVIESVKRLIRDVI IUTMFSLSVFALMGLOIYMGVLTQKC 300 FRVL_RALKTVAIVTGLKTTVGAVIESVKHLRDVITUTMFSLSVFALMGLQIYMGVLTQKC 73

IREFPMDGSWGMLSDENIKERPHNWDSNWYFSETGDTPLCGNSSGAGQCEEGYICLQGYGD 760

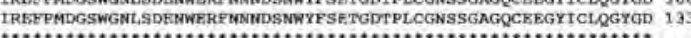

NPNYGYTSFPTFGWAFI,SAFRMTOOWWENLYOLVLRSAGPWHMLFFTVITFLGSFYLVW 420 MPNYGYTSFDTFGWAFLSAFELMTODYWENL YDLVLRSAGPWEMLFFIVIIFLGSFYLVN 19

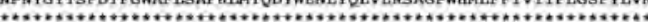

1.TLATVAMSYDRT/OKRAREREAAREEAL.REAREAANAKAAKI.EAQAAAAAAAANPEIAKS 4 G0

PSDFSCHSYELFVNQEKGNDDUNKEKMS IRSEGLESVSETTRTTAPTATAAGTAKARKVS 540 PSDPSCHSYELFWQRKCM

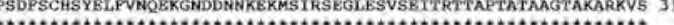

AASLSLPGSPFERRGSRGSHQFTIRNGRERFVGVPSDRKPLVLSTYLDAQEHT.PYADD 600 AASLSLPGSPENLRRGSRGSHQYTIRNGRGRYVGVGSDRKPLVLSTYLDAQEHLEYADU 373

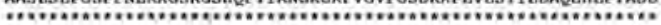

SHAVTPMSEENGAITVPVYYANLCGSHSSYTSHQSRISYTSHGDLLGGMTRESRLRNRSA 660 SRAVTPHSEENGAIIVPYYYANLGSRHSSYTSBQSRISYTSHGDLLGGMTKESRLRARSA 433

RNTNHSIVPPPWMSGPNMSYVDSNHKGQRDYDMSQDCTDEACKKIKHWDNHF IEPTOTVIV 720 RNTNHSTVPPPMMSGPNMS YVDSNHKCORDFDMSODCTDEACKIKHSDNEF IEPSOTOTV 493

VDMKDVMVLADI IROANGRHSRASDHGVSVYYFPTEDODEDGPTFKDKALEFTMEMIDVP 780 VDMKDVMVLARDI IEOAAGRHSRASDHGVSVYYFPTEDDDEDGPTFKDKALEFTMRMIDVF 553

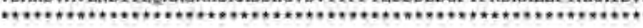

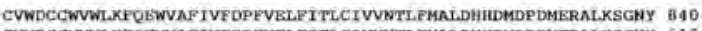
CVWDCCWVWLKFQEWVAFIVFDPFVELFITLCI VVNTL,FMALDHHDMDPDMERNLKSGEY 613

PPTATPATEATMKLLIAMSPKYYFQEGWHTFPTIVALSLLEL_ALEGVQGLSVL.RSFRL.L.R 900

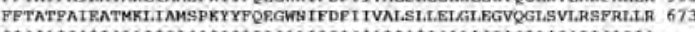

VFKLAKSWPTLALLISIMGRTMGALGKLTFVLCIIIFIFAVMGMOLFGKWYIDWVDRPPD 960 VFKLAKSWFTLRLLIS IMGRTMGALGGLTFVLCTIIFIFAVMGMOLFGKWY IDNVDRFPD 731.

KDLPRWUFTDFMHSFMTVFRVLCCEWIESMWOCMLVEDVSCIPEFLATVVI GNLVVI.NLE 1020

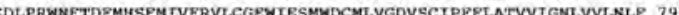

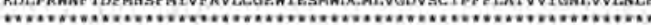

LALI.TSWFOSSSLSAPTADNETNKIAEAFNRISRESNWIKSNIANAL,KFVKMKLTSOIAS 1080

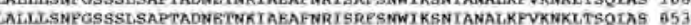

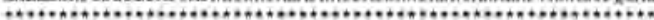

para-1ike

NABL $006019-\mathrm{PC}$

para-1ike

MAEL006019-PC

parn-like

Mats-006019-PO

para-1ike

AAEL006019 - EC

pare-1ike

AAEL006019-PC

pard-1ike AMEL $006019-\mathrm{PC}$

para-like MUEL006019-PC

para-1ike: AAEL006019-PC

para-1ike AAEL.006019-PC: MNELQ6019-FC

para-like Mard-1006019-PC

pard-1ike AASZ006019-DC

para-1 tike ANEL006019-PC

para-1 1 Kke MAER.006019-PC:
VQPAGBQHNHTSWTWNEGKGGVCPCISAEHGENELELTPDDTLADGHLKKGVVEHNQLEVA 1140 W.

IGDGMEPTTHGDLKNKGKKNKQLMNNSKVIGNSI SNHQDNKLEHEL.NHRGMSLQDDOTAS 1200 IGDGMEFT'IHGDLKNKGKKNKQLMNNSKVIGNSISNHQDNKLEHELNHRGHSLODDDYAS 960

IKSYGSHKHRPEKDESHKCSAETMEGEEKRDYSKEDTGIDERLDDECDGEEGPLDELIII 1260 IRSYGSHKNHPFKDESHKGSAETMEGEEKRDUS KERLGIDERLDDECDGEEGPLDGELII 1020

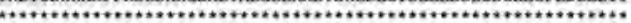

AIADEDEVIKDSEADCCPDNCYKKFEVLAGDDDAPFWQGEWARLRLKTFQLIENKYFBTAVI 1320 HADEDEVIEDOSPADCCPDNCYKKFPVLAGDDDAPFWQCWARLFLKTFQLIENKYFETAVI 108

TMILLSST.ALAL.EDVHLPHRPILODVI.YYMDRTPTVIPPLERLIKWLALCERVYPTYANC 1380 TMILISSSLALALEDVHLPHRPILODVLYYMDRIFTVIE FLEMLIKWLALCERVYFTRAWC 114

M.DETIVMVST.INFVASLCGAGGIDAFKTMRTLRALRPLIRAMSRMOGIMRVVVAALVQATP 1440

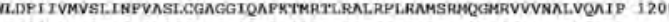

STENVILVCLIFWLTFAIMGVQT.FAGKYFKCVDKNKTILSHET IPDVNACVAENYTWENS 1500

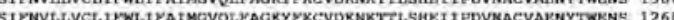

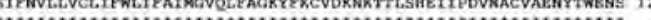

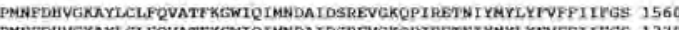
PMNFDHVGKAYLCLEQVATFKGWIQIMNDAIDSREVGKOPIRETSTYMYLYFVFFIIFGS 1320

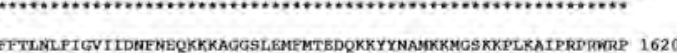
FFTLNLFIGVI IDAFNEQKKKAGGSLEMFMTEDQKKYYNAHKKMGSKKPL KATPFPPWRP 13日0

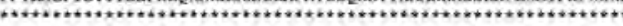

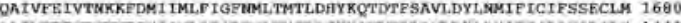

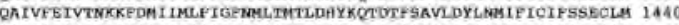

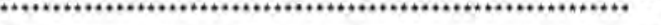

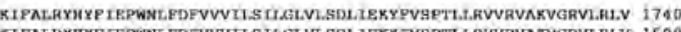
KIFNL.FYIIYF IEPWNLFDFVVVILS SLLLVLLSDLIEKYFVIPTLLLRVVRVARVGRVLALV 1500

KGAXGTATLLFALAMSLPALFICLCLFLVMY TFAIFCMSFFMHVKDKSGLDOVYNEKTE 1800

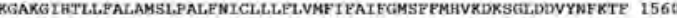

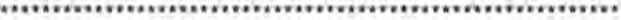

GQSMILLFONSTSAGWDGVLDGIMEDECL.PPDEDKGYPGNCGSATIGITYLLAYLVISF 1 घ60 GQSMTILIFOMSTSAGWDGVI.DGI INEDECL.PPDNDKGYPGNCGSNTIGITYLTAYIVISF 1620

LIVINEYIAVILEAYSQATBDVQEGLTODDYDMYYE NWQPFDPDGTQYIHXDOLSDFL,DV 1920

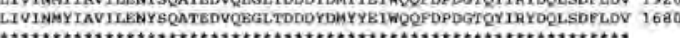

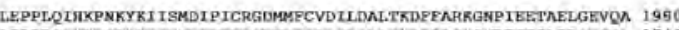
LEPPLQTHKPNKYKI ISMDIPICRCGDMUPCVDILDALTKDFEARKGKPTEETAELGEVQA 174

PPDSVGYEPVSSTLWRQREEYCARVI QHAWRKHKERQAGGGEGDDTDADACDNDDGDDGG 2040 RPDEVGYSPVSSTLWROREEYCARVIOIIAWKKIIKEROAGGOGGDDTDADACD\&DDGDGG 1800

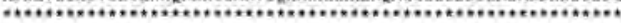

GIAGDGGSAGGGGVTSPGVUSGSIVGGGTTPGSGGGGSOANLGIVVEHNL.SFKESPDGKN 210

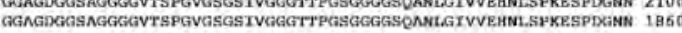
DPQGRQTAVLVESDGFVTKSGKHVVIHSRSPSITSHSADV 2140 DPOGRQTAVLVESDGEVTKAGHRVYIHSRSPSITSHAADV 190

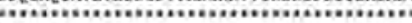

